\title{
Microscale heterogeneity in the activity of coastal bacterioplankton communities
}

\author{
Justin R. Seymour ${ }^{1, *}$, James G. Mitchell ${ }^{1}$, Laurent Seuront ${ }^{1,2}$ \\ ${ }^{1}$ Biological Sciences, Flinders University, PO Box 2100, Adelaide, South Australia 5001, Australia \\ ${ }^{2}$ Ecosystem Complexity Research Group, Station Marine de Wimereux, CNRS-UMR 8013 ELICO, \\ Université des Sciences et Technologies de Lille, 28 avenue Foch, 62930 Wimereux, France
}

\begin{abstract}
Microscale sampling techniques and flow cytometry were employed to measure the distribution patterns of 8 subpopulations of bacteria separated according to variations in cell fluorescence and light scatter properties. Subpopulations of bacteria defined on the basis of these parameters have recently been shown to represent cells exhibiting dissimilar activity levels, and we therefore assume that the subpopulations of bacteria identified here represent metabolically diverse groups. Microscale distribution patterns of these subpopulations were measured at a resolution of 4.5 and $12 \mathrm{~mm}$, within 2 dissimilar coastal habitats. A mean 2-fold change in the abundance of the total bacterial community across sample sets was observed. However, levels of spatial heterogeneity were consistently higher for the cytometrically defined subpopulations than total counts. In most samples, the population of bacteria exhibiting the highest levels of green fluorescence, or DNA content, and hence assumed to represent the most active bacteria in the community, also showed the highest levels of microscale spatial variability, with a maximum change in abundance of 14.5-fold observed across a distance of $9 \mathrm{~mm}$. Where Zipf rank-size analysis was conducted, the microscale distributions of subpopulations differed significantly $(p<0.05)$ in $79 \%$ of cases, implying that bacterial communities are made up of physiologically distinct compartments, perhaps influenced by different microscale features of the environment. We suggest that these results provide the first evidence for the existence of microscale heterogeneity in the metabolic activity of aquatic bacterial communities.
\end{abstract}

KEY WORDS: Marine bacteria · Microscale heterogeneity · Flow cytometry · Single cell activity

Resale or republication not permitted without written consent of the publisher

\section{INTRODUCTION}

Populations of heterotrophic bacteria represent a fundamental element in ocean carbon cycling processes, and a thorough understanding of how marine microbes interact with the local environment and other organisms is subsequently of relevance to marine food web structure (Azam et al. 1983), biogeochemical processes (Azam 1998, Bidle \& Azam 1999, Kiene et al. 2000, Azam \& Long 2001, Simo et al. 2002), and ultimately climate change models (Ducklow \& Fasham 1992, Kiene et al. 2000). Accordingly, bacterioplankton abundance, community composition and productivity have become principle measurements in oceanographic ecosystem studies.

Traditionally, bacterioplankton communities have been characterised by water samples ranging in vol- ume from several millilitres to litres, collected across scales of metres to tens of kilometres. While this approach has helped to generate a broad impression of communities and environments, marine bacteria inhabit microenvironments defined on spatial scales of less than $1 \mathrm{~cm}$. It is at this microscale that important ecological processes including predation, nutrient uptake and infection occur amongst microbial communities, and that patchiness of dissolved substrates and organic particles is likely to exist (Lehman \& Scavia 1982, Blackburn et al. 1997, 1998, Azam 1998, Kiørboe et al. 2001, Seuront et al. 2002). Consequently, heterogeneity in the abundance, diversity and activity of microbial communities may occur from one drop of seawater to another, ultimately influencing several ecological and biogeochemical processes in the ocean (Azam 1998, Long \& Azam 2001). 
Microscale patchiness in the abundance of bacterioplankton communities has indeed been observed across distances of centimetres (Mitchell \& Fuhrman 1989, Duarte \& Vaqué 1992), millimetres (Seymour et al. 2000) and micrometres (Krembs et al. 1998). Recently, Long \& Azam (2001) also identified millimetre-scale heterogeneity in the species richness of bacterioplankton communities, indicating that microscale variability in bacterioplankton community composition may sometimes exceed the levels of phylogenetic variability observed at large scales (Riemann et al. 1999, Riemann \& Middelboe 2002). They attributed these microscale changes in community composition to bacterial interactions with specific microhabitats associated with particulate organic matter (Long \& Azam 2001). Microscale variability in bacterial growth and activity is also anticipated to occur in response to heterogeneities in the distribution of organic material in the ocean (Azam 1998, Kiørboe \& Jackson 2001). However, while coherent shifts in the activity of bacterioplankton communities have been widely observed across larger scales (del Giorgio \& Scarborough 1995, del Giorgio et al. 1997, Gasol et al. 1998, 2002, del Giorgio \& Bouvier 2002, Riemann \& Middelboe 2002), to our knowledge the existence of microscale variation in bacterial activity has yet to be shown. If a persistent feature of the marine environment, microscale heterogeneity in bacterial activity could have critical implications for calculations of bulk bacterial growth and biogeochemical transformation rates, because specific microzones or 'hotspots', where bacterial activity significantly exceeds background levels, may be missed by bulk analysis techniques.

A variety of analytical techniques have been applied to the measurement of single cell activity in communities of aquatic bacteria (Rodriguez et al. 1992, Zweifel \& Hagström 1995). Amongst these, flow cytometry has recently been increasingly employed to differentiate subpopulations of bacteria, by means of measuring variations in the light scatter properties (related to size and biovolume) and DNA content of individual cells (Li et al. 1995, Marie et al. 1997, Gasol et al. 1999). Up to 7 discrete subgroups of bacteria have been discriminated using this technique (Troussellier et al. 1999), but generally 2 to 3 main groups of bacteria represented as high DNA (HDNA) and low DNA (LDNA) populations are characterised in aquatic samples (Li et al. 1995, Gasol et al. 1999). An extensive compilation of field- and laboratory-based studies suggest that these variations are related to single cell activity, with HDNA cells constituting the active proportion of natural bacterial communities, while LDNA cells appear to represent dormant or dead cells (Li et al. 1995, Jellett et al. 1996, Gasol et al. 1999, 2002, Servais et al. 1999, Yanada et al. 2000, Lebaron et al. 2001, Vaqué et al. 2001). It has subsequently been proposed that the percentage of HDNA bacteria may be applied as an accurate indication of the proportion of active cells within a community (Jellett et al. 1996, Gasol et al. 1999). Lebaron et al. (2002), however, recently identified over a 9-fold change in specific activity across the HDNA population alone, and showed that specific activity is strongly correlated to both the fluorescence and scatter properties of cells. Due to the wide range of fluorescence and scatter values observed within natural bacterial populations (Li et al. 1995, Lebaron et al. 2002), and the ability to differentiate specific subpopulations according to these parameters (Troussellier et al. 1999, Andreatta et al. 2001, Lebaron et al. 2002), it follows that flow cytometry has the potential to identify multiple groups of bacteria, perhaps spread across a continuum of activity levels. This is likely to provide a more realistic impression of bacterioplankton communities than is obtained by simply dividing the population into either active or inactive compartments, as is achieved by other single cell activity measurements (Berman et al. 2001, Smith \& del Giorgio 2003).

In the present study we applied microscale sampling procedures (Seymour et al. 2000, Waters et al. 2003) and flow cytometric analysis techniques to investigate the distributions of several cytometrically defined subpopulations of bacterioplankton within coastal seawater samples. These subpopulations were subsequently characterised both qualitatively and quantitatively in terms of spatial distribution and community structure complexity. In accordance with the assumption that these subpopulations represent groups of bacteria with varying degrees of activity (Lebaron et al. 2002), we suggest that our findings represent the first evidence for microscale heterogeneity in the activity of natural marine bacterial assemblages.

\section{MATERIALS AND METHODS}

Sampling sites. Microscale measurements of bacterial distribution patterns were made at 2 coastal sites in the metropolitan area of Adelaide, South Australia. The Port River and Port Noarlunga study sites employed were chosen because (1) they have bacterial communities that differ in total concentration by approximately 1 order of magnitude, (2) they have previously been shown to harbour communities that exhibit varying levels of microscale spatial heterogeneity (Seymour et al. 2000), and (3) they exhibit dissimilar hydrodynamic regimes and nutrient conditions.

At Port Noarlunga $\left(35^{\circ} 09^{\prime} \mathrm{S}, 138^{\circ} 28^{\prime} \mathrm{E}\right)$ samples were taken from the end of a coastal jetty situated approximately $150 \mathrm{~m}$ from the shore-line, where the depth of the water column was approximately $8 \mathrm{~m}$. This sam- 
pling site is generally characterised by relatively oligotrophic conditions, and high levels of turbulence associated with waves breaking over a semi-submerged rocky reef situated approximately $10 \mathrm{~m}$ to the seaward side of the sampling point. In the Port River estuary $\left(34^{\circ} 49^{\prime} \mathrm{S}, 138^{\circ} 30^{\prime} \mathrm{E}\right)$, samples were taken from a floating pontoon platform, where the depth of the water column was approximately 8 to $10 \mathrm{~m}$. The Port River site is generally characterised by eutrophic conditions, influenced by high levels of urban and industrial waste and intermittent flow of fresh water.

Samples were collected from the Port River and Port Noarlunga sites on 4 sampling occasions between March and October 2002. At each site, bulk surface water conditions were measured and recorded using a Hydrolab DataSonde ${ }^{\circledR} 4 a$. Samples for chlorophyll extraction were collected in triplicate $(100 \mathrm{ml})$ and filtered through $0.45 \mu \mathrm{m}$ HA filters. Chlorophyll was extracted in $90 \%$ acetone and assayed using a Turner 10AU fluorometer.

Microscale sampling techniques. We used 2 sampling devices, both based on equipment previously used to investigate microscale distributions of bacteria and phytoplankton (Seymour et al. 2000, Waters et al. 2003), to measure shifts in the distribution of bacterioplankton populations at each site.

The first of these consisted of two 8-place autopipettes (Brand Transferpipette- $8^{\circledR}$ ) connected to form a linear series of 16 sample tips, each separated by a distance of $4.5 \mathrm{~mm}$. This device allowed the simultaneous collection of $50 \mu \mathrm{l}$ subsamples across a horizontal 1-dimensional transect, approximately $5 \mathrm{~cm}$ below the water surface. At each site, 4 replicate transects were collected from approximately the same point in the water column, at intervals of $2 \mathrm{~min}$, allowing for comparisons of within- and between-sample variation.

Secondly, a sampling device allowing for the examination of bacterial distributions in 2 dimensions, and hence presenting a clearer representation of the spatial structure of bacterial communities than the linear sampling device, was employed. This spring-loaded system consisted of a $10 \times 10$ matrix of $1 \mathrm{ml}$ syringes, each separated by a distance of $1.2 \mathrm{~cm}$ and set to sample volumes of $100 \mu \mathrm{l}$. A messenger weight triggered the sampling mechanism allowing for the simultaneous collection of 100 subsamples across $116 \mathrm{~cm}^{2}$. While this device can be used to take samples anywhere from the surface to $25 \mathrm{~m}$ depth, during this study samples were taken from a depth of approximately $1 \mathrm{~m}$.

Flow cytometry analysis of samples. Immediately after collection, all subsamples were transferred to $1 \mathrm{ml}$ cryovials and incubated with $2 \%$ (final conc.) paraformaldehyde in the dark for $20 \mathrm{~min}$, before being quick-frozen in liquid Nitrogen and then stored at $-80^{\circ} \mathrm{C}$. Prior to flow cytometry analysis, frozen samples were quickly thawed, and transferred to $5 \mathrm{ml}$ cytometry tubes. Samples were then stained with SYBR-I Green solution (1:10000 dilution; Molecular Probes), and incubated in the dark for 15 min (Marie et al. 1997, 1999).

Fluorescent beads of $1 \mu \mathrm{m}$ diameter (Molecular Probes), were added to samples in a final concentration of approximately $10^{5}$ beads $\mathrm{ml}^{-1}$ (Gasol \& del Giorgio 2000), and all measured cytometry parameters were normalised to bead concentration and fluorescence. After each flow cytometry session, working bead solutions were enumerated using epifluorescent microscopy to ensure consistency of the bead concentration (Gasol \& del Giorgio 2000). Flow cytometry analysis was conducted using a Becton Dickinson FACScan flow cytometer, with phosphate-buffered saline (PBS) solution employed as a sheath fluid. For each sample, forward-angle light scatter (FSC), rightangle light scatter (SSC), green (SYBR-I) fluorescence, red fluorescence, and orange fluorescence were acquired. Acquisition was run until at least 40 to $100 \mu \mathrm{l}$ of the sample had been analysed at a rate of approximately $40 \mu \mathrm{lmin}{ }^{-1}$. To avoid coincidence of particles, it was ensured that the rate of analysis was kept below 1000 events $\mathrm{s}^{-1}$ by diluting samples with $0.2 \mu \mathrm{m}$ filtered seawater where necessary (Gasol \& del Giorgio 2000). Data for individual subsamples was collected in listmode files, and subpopulations of bacteria were separated using Win Midi 2.8 ( ${ }^{\oplus} \mathrm{Joseph}$ Trotter) and CYTOWIN (Vaulot 1989) flow cytometry analysis software. Discrete populations of bacteria were identified according to variations in green fluorescence (FL1) and light side scatter (SSC).

Characterisation of microscale variability. We quantified the degree of spatial variability observed for a given population across a sample set by calculating the absolute change in abundance of the population and a coefficient of variation (CV) for that change. The application of the coefficient of variation is useful here because, unlike many measures of variability, it is insensitive to the magnitude of the data, allowing for direct comparison between populations which may differ in concentration by orders of magnitude. Kolmogorov-Smirnov and Shapiro-Wilks tests for normality and related skew values were calculated to investigate the nature of the distributions of each population.

To further quantify microscale variability in the spatial patterns of the cytometrically defined subpopulations of bacteria and community composition as a whole, we used 2 related but conceptually different analysis methods. The first method is based on a rank-size analysis, also referred to as Zipf analysis (Zipf 1949), which has previously been widely used to study the structural nature of distributions within fields as diverse as physics, linguistics, economics, 
human demographics and molecular biology (Hill 1970, Wyllys 1975, Ridley \& Gonzalez 1994, Stanley et al. 1995, Gunther et al. 1996, Marsili \& Zhang 1998, Li \& Yang 2002), and has recently been applied to the investigation of 1-dimensional phytoplankton distributions (Mitchell 2004) and 2-dimensional microphytobenthos distributions (Seuront \& Spilmont 2002).

Zipf analysis considers the observation that the frequency, size or magnitude of an occurrence $(S)$, as a function of its rank $(r)$, when $r$ is determined by the above frequency, size or magnitude, is a power-law function that can be described by:

$$
S=k r^{-b}
$$

where $k$ is a constant and $b$ is estimated as the slope of the log-log plot of $S$ versus $r$. This technique can be used to identify the degree of structure within a distribution, in terms of the shape of the Zipf plot and the extent of a power-law behaviour. Rather than exhibiting a power-law behaviour, ranked uniform distributions will be characterised by a linear behaviour, because all values in a uniform distribution have equal probability of occurring. On a log-log plot, such distributions are characterised by a continuous roll-off from a horizontal to vertical line (see present Fig. 4A; Mitchell 2004). Other models of randomness (e.g. normal and Poisson distributions) exhibit similar patterns (see Fig. 4A). Alternatively, distributions displaying significant structure exhibit a power-law behaviour, and increasing exponent $(b)$ values indicate increasing levels of structural complexity (Mitchell 2004). Subsequently, this technique can be applied as a quantitative comparison of the structural complexity of the distributions of different populations or samples.

Here we calculated the Zipf exponent $(b)$ values for the distributions of each of the bacterial populations identified within the 2 -dimensional $10 \times 10$ data sets. As it has been demonstrated that a sample size of $n=$ 16 is the lower limit for accurately analysing Zipfian data (Alon et al. 2002), Zipf analysis was only applied to the 2-dimensional data sets $(N=100)$ here. Within these data sets, the relative abundances of cells for a given population, within the 100 subsamples, were ranked from 1 to 100 . These were then plotted on a log-log graph of cell concentration versus rank (see Fig. 4A). Rank distributions can in some cases be contaminated by random noise, but this does not produce a power-law behaviour, and is easily identifiable as a downward roll-off over high rank values, and can therefore be readily omitted from the analysis (see Mitchell 2004). As a consequence, the values associated with these roll-offs were omitted from the analysis here, and a power-law fit was then applied to the linear feature of the plot (see Fig. 4A). The exponent (b) of the fitted power law was then calculated for each population, and least squared regression analysis, utilising a modified Student's $t$-test, was performed to determine whether the $b$ value for each of the populations differed significantly from 0 (Zar 1984). To identify differences between the distributions of different subpopulations, $95 \%$ confidence intervals for $b$ were calculated from the exponent standard error $(b[\mathrm{SE}])$ as $95 \% \mathrm{CI}=$ $b \pm(b[\mathrm{SE}] \times t(2)(\mathrm{n}-2)$ using SPSS Version 11.0 statistical software.

A second method, based on a modified application of the rank-size technique, was also used to investigate microscale variability in the structure of bacterial community composition, by investigating shifts in the relative proportions of bacterial subpopulations between samples. In this case, rather than ranking the concentrations of a given population across an entire sample set, the cytometrically defined populations of bacteria within each subsample were ranked according to their relative abundance, so that in the case of 8 populations the most numerically abundant population would be ranked as 1, while the least abundant population would be ranked as 8 . This allowed us to characterise the nature of the community composition within each subsample. Using this technique we could identify microscale changes or patterns in the relative numerical importance of a given population within the community by determining how its rank varied between subsamples.

We additionally investigated microscale shifts in the total organisation of the community by calculating the average 'distance' between rank distributions. A 'distance' is here defined as a quantitative measure of the difference in rank distribution of populations between 2 different samples. For a given population of bacteria $\left(B_{1}\right)$, the distance $(d)$ between its rank in Samples 1 and 2 can thus be given (Havlin 1995) by:

$$
d_{12}\left(B_{1}\right)=\left[r_{1}\left(B_{1}\right)-r_{2}\left(B_{1}\right)\right]^{1 / 2}
$$

where $r_{1}\left(B_{1}\right)$ is the rank of population $B_{1}$ in Sample 1 and $r_{2}\left(B_{1}\right)$ is the rank of the same population in Sample 2 . The total distance between the 2 samples, incorporating all populations of bacteria, $B_{i}$, is defined as the mean square root distance between the ranks of all common populations (Havlin 1995):

$$
d_{12}=\left[\frac{1}{N} \sum_{i=1}^{N}\left(r_{1}\left(B_{i}\right)-r_{2}\left(B_{i}\right)\right)^{2}\right]^{1 / 2}=\left[\frac{1}{N} \sum_{i=1}^{N} r_{12}^{2}(B)\right]^{1 / 2}
$$

where $N$ is the total number of common populations, $B_{i}$, observed in both samples. We employed this quantification of distance between rank distributions as an indication of the overall change in community structure between subsamples and between sample sets. 


\section{RESULTS}

\section{Comparison of study sites and communities}

Mean temperature and salinity measurements were $16^{\circ} \mathrm{C}$ and $36.5 \%$, and $18.5^{\circ} \mathrm{C}$ and $35.2 \%$, for the Port Noarlunga and Port River sites respectively. The Port River site was characterised by significantly higher mean chlorophyll a levels $\left(16.5 \mu \mathrm{g} \mathrm{l}^{-1} \pm 3.8 \mathrm{SD}\right)$ than Port Noarlunga (2.2 $\left.\mu \mathrm{g} \mathrm{l^{-1 }} \pm 1.9 \mathrm{SD}\right)$, and mean concentrations of bacteria within the Port River $\left(3.0 \times 10^{6}\right.$ cells $\mathrm{ml}^{-1}$ ) were also approximately an order of magnitude

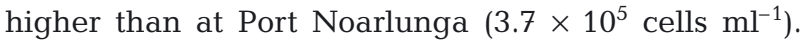
Average mixing levels in the protected Port River estuary were always much lower than in the exposed coastal site at Port Noarlunga, with average turbulent energy dissipation rates of $7.5 \times 10^{-8}$ and $3.6 \times 10^{-5} \mathrm{~m}^{2}$ $\mathrm{s}^{-3}$ characteristic of the Port River and Port Noarlunga sites respectively (J. R. Seymour \& L. Seuront unpubl. data).

\section{Flow cytometry differentiation of bacterial subpopulations}

Flow cytometry analysis of samples revealed significant variability in the structure of the bacterial community between study sites. At both sites separation of the bacterial community into high DNA (HDNA) and low DNA (LDNA) categories, as discussed in detail elsewhere (e.g. Jellett et al. 1996, Gasol et al. 1999, Lebaron et al. 2001), was evident (Fig. 1A). HDNA
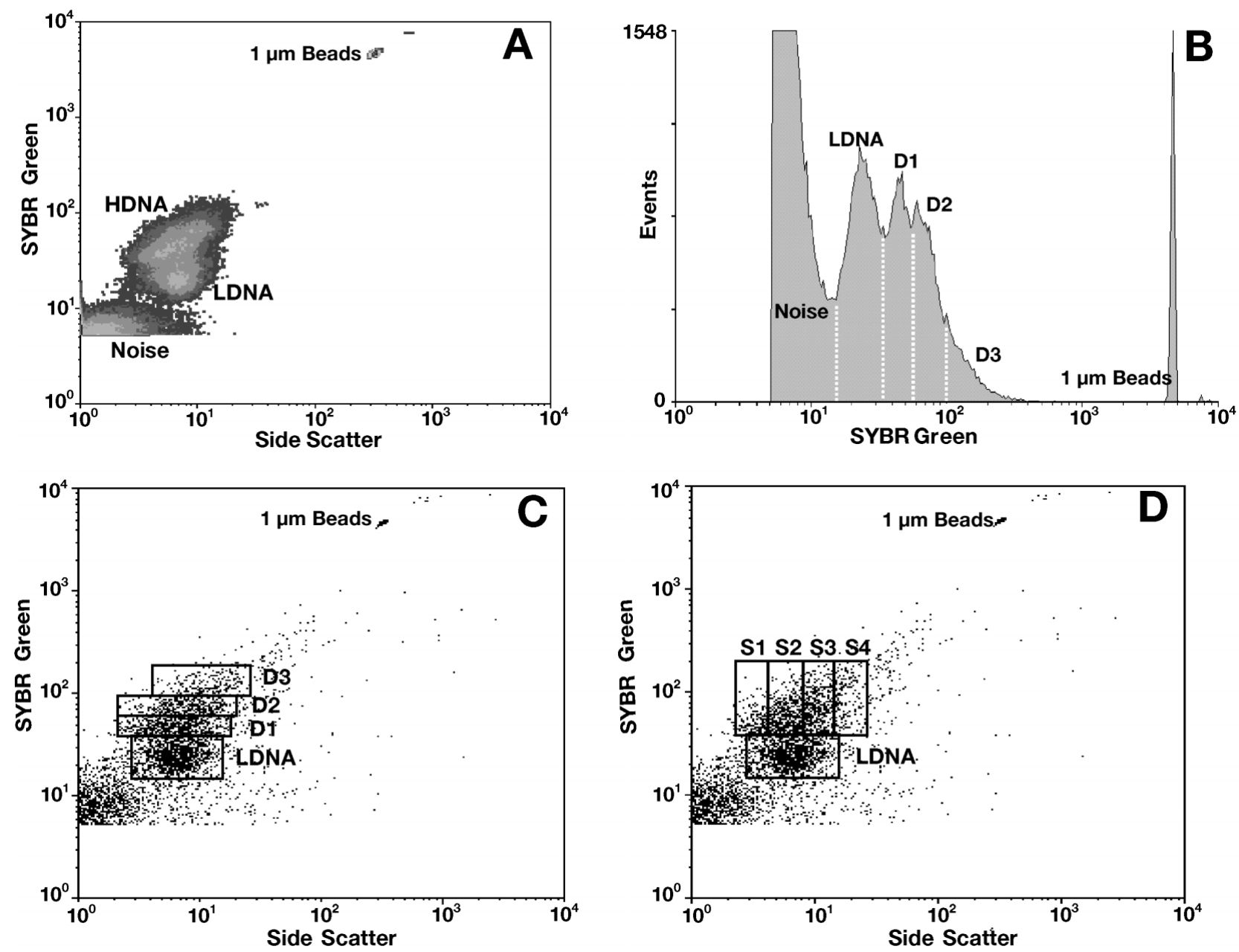

Fig. 1. Cytometric differentiation of bacterial populations. (A) Differentiation of low-DNA (LDNA) and high-DNA (HDNA) populations of bacteria in a plot of side-angle light-scatter versus green fluorescence. (B) Histogram plot of green fluorescence showing peaks relating to LDNA population and 3 other subpopulations of increasing DNA content (D1, D2, D3). (C) Scatter-plot of side-angle light-scatter versus green fluorescence showing corresponding differentiation of LDNA, D1, D2, D3 populations. (D) Scatter-plot of side-angle light-scatter (SSC) versus green fluorescence showing arbitrary differentiation of populations (S1 to S4) performed according to variations in SSC 
populations generally exhibited slightly higher sidescatter, and mean green fluorescence levels were 2.5 times higher in the HDNA than the LDNA population. The mean relative percentage of HDNA cells varied from $53 \%$ within the Port River bacterial community to $74 \%$ at Port Noarlunga.

At both sites, 3 separate subpopulations within the HDNA population could also be identified on green fluorescence histograms (Fig. 1B). In all samples, 4 discrete peaks were evident in green fluorescence histograms, corresponding to the LDNA population and 3 other subpopulations of increasing DNA content, referred to as D1, D2 and D3 hereafter. These were then identified on corresponding scatter-plots of green fluorescence (DNA content) versus side-scatter (SSC) (Fig. 1C). Green fluorescence levels varied by up to 5 times across the bacterial population, from the LDNA to the D3 subpopulations, with a concomitant 2.9-fold increase in SSC and slight increase in forward-scatter (FSC) also occurring (Table 1).

While relative changes in SSC across the bacterial populations at both sites often exceeded 4 -fold (Table 1), separation of discrete subgroups of bacteria according to variations in SSC was generally not evident on histograms or cytograms. Subsequently, bacterial populations were divided into 4 equally sized regions, separated according to increasing SSC

Table 1. Normalised fluorescence and scatter values for cytometrically defined subpopulations of bacteria. All forwardangle light-scatter (FSC), side-angle light-scatter (SSC), and SYBR Green fluorescence (FL1) values are normalised to scatter and fluorescence properties of $1 \mu \mathrm{m}$ fluorescent beads (Molecular Probes). BII, BIII: populations identified by Marie et al. (1997); other abbreviations as in Fig. 1

\begin{tabular}{|lccc|}
\hline & FSC & SSC & FL1 \\
\hline Port Noarlunga & & & \\
LDNA & 0.58 & 0.057 & 0.016 \\
D1 & 0.61 & 0.058 & 0.031 \\
D2 & 0.64 & 0.077 & 0.047 \\
D3 & 0.73 & 0.118 & 0.075 \\
S1 & 0.56 & 0.032 & 0.035 \\
S2 & 0.55 & 0.054 & 0.038 \\
S3 & 0.57 & 0.088 & 0.042 \\
S4 & 0.66 & 0.144 & 0.053 \\
BII & 0.67 & 0.041 & 0.035 \\
BIII & 0.7 & 0.083 & 0.042 \\
Port River & & & \\
LDNA & 0.56 & 0.053 & 0.015 \\
D1 & 0.58 & 0.054 & 0.026 \\
D2 & 0.62 & 0.071 & 0.038 \\
D3 & 0.77 & 0.129 & 0.064 \\
S1 & 0.57 & 0.031 & 0.028 \\
S2 & 0.58 & 0.047 & 0.031 \\
S3 & 0.61 & 0.074 & 0.037 \\
S4 & 0.78 & 0.141 & 0.052 \\
& & & \\
\hline
\end{tabular}

(Fig. 1D). This permitted a comparison with other papers that employ arbitrary division of populations with respect to changing SSC (Lebaron et al. 2002), and an analysis of the distribution patterns of groups of

Table 2. Distributional statistics for cytometrically defined subpopulations of bacteria in samples collected from Port Noarlunga, South Australia. Skew values in bold print represent distributions that significantly differ from normal $(p<$ 0.05), assessed using Kolmogorov-Smirnov (for $10 \times 10$ data sets), and Shapiro-Wilks (for linear sample sets) tests for normality. Abbreviations as in Fig. 1 and Table 1

\begin{tabular}{|c|c|c|c|c|}
\hline $\begin{array}{l}\text { Sample } \\
\quad \text { Population }\end{array}$ & $\begin{array}{c}\text { Mean } \\
\left(\times 10^{5} \mathrm{ml}^{-1}\right)\end{array}$ & $\begin{array}{l}\mathrm{CV} \\
(\%)\end{array}$ & Skew & $\begin{array}{c}\text { Absolute } \\
\text { change }\end{array}$ \\
\hline \multicolumn{5}{|l|}{ Linear 1} \\
\hline Total & 3.9 & 7.5 & -0.18 & 1.3 \\
\hline$\%$ HDNA & 73 & 6.6 & -2.88 & 1.4 \\
\hline LDNA & 1.1 & 16.6 & 1.99 & 1.9 \\
\hline D1 & 1.8 & 7.6 & 0.65 & 1.3 \\
\hline D2 & 0.94 & 26.3 & -1.04 & 4.5 \\
\hline D3 & 0.11 & 39.1 & 0.03 & 8.2 \\
\hline BII & 1.7 & 12.4 & -1.12 & 1.7 \\
\hline BIII & 1.1 & 8.9 & -0.05 & 1.4 \\
\hline \multicolumn{5}{|l|}{ Linear 2} \\
\hline Total & 4 & 18.2 & 2.08 & 2.1 \\
\hline$\%$ HDNA & 76.3 & 2 & 0.39 & 1.1 \\
\hline LDNA & 0.97 & 19.8 & 0.99 & 2.3 \\
\hline D1 & 1.9 & 18.5 & 2.43 & 2 \\
\hline D2 & 1 & 21.7 & 1.33 & 2.2 \\
\hline D3 & 0.13 & 29.8 & 1.08 & 2.3 \\
\hline BII & 1.7 & 17.6 & 2.13 & 2 \\
\hline BIII & 1.2 & 18.7 & 2.37 & 2.1 \\
\hline \multicolumn{5}{|l|}{ Linear 3} \\
\hline Total & 3.9 & 10 & -2.38 & 1.5 \\
\hline$\%$ HDNA & 76.5 & 1.9 & -0.89 & 1.1 \\
\hline LDNA & 0.92 & 10.8 & -1.4 & 1.6 \\
\hline D1 & 1.9 & 12.6 & -1.48 & 1.7 \\
\hline D2 & 0.96 & 17.4 & 0.22 & 1.9 \\
\hline D3 & 0.13 & 41.9 & 0.98 & 3.4 \\
\hline BII & 1.7 & 9.9 & -1.64 & 1.5 \\
\hline BIII & 1.2 & 11 & -2.05 & 1.6 \\
\hline \multicolumn{5}{|l|}{ Linear 4} \\
\hline Total & 3.6 & 11.8 & -0.6 & 1.6 \\
\hline$\%$ HDNA & 74.1 & 7.4 & -1.68 & 1.3 \\
\hline LDNA & 0.91 & 19.4 & -0.07 & 1.9 \\
\hline D1 & 1.8 & 14.5 & -0.28 & 1.8 \\
\hline D2 & 0.8 & 37.4 & -0.68 & 7 \\
\hline D3 & 0.09 & 52.8 & -0.09 & 12.6 \\
\hline BII & 1.5 & 15.4 & -1.01 & 1.9 \\
\hline BIII & 1.1 & 14.5 & -0.8 & 1.7 \\
\hline \multicolumn{5}{|l|}{$10 \times 10$} \\
\hline Total & 3 & 10 & -0.6 & 2 \\
\hline$\%$ HDNA & 68.2 & 7.5 & -0.64 & 1.4 \\
\hline LDNA & 0.95 & 16.8 & 0.55 & 2.6 \\
\hline $\mathrm{D} 1$ & 1.1 & 13 & -0.28 & 2.9 \\
\hline $\mathrm{D} 2$ & 0.7 & 19.9 & 0.08 & 3 \\
\hline D3 & 0.28 & 25.5 & 0.34 & 6.4 \\
\hline $\mathrm{S} 1$ & 0.31 & 20.1 & 0.14 & 2.7 \\
\hline $\mathrm{S} 2$ & 0.68 & 17.1 & 0 & 2.3 \\
\hline S3 & 0.76 & 12.7 & -0.15 & 2 \\
\hline S4 & 0.28 & 12.8 & 1.31 & 2.5 \\
\hline
\end{tabular}


bacteria within different size or biovolume categories (Button et al. 1996). This arbitrary division of populations according to SSC was employed for all samples, with the exception of those collected from Port Noarlunga on 16 October 2002, where 2 subpopulations of cells with approximately identical DNA content but varying SSC levels, similar to the BII and BIII populations identified by Marie et al. (1997), were observed. In this case the population was divided and named with reference to these BII and BIII populations. Across all populations of increasing SSC, concomitant slight increases in green fluorescence and FSC were observed (Table 1).

\section{Microscale heterogeneity in abundance of bacterial populations}

Microscale variability in the abundance of the total bacterial population was comparable between the 2 study sites (Tables $2 \& 3$ ). A mean shift in total abundance within sample sets of approximately 2 -fold was observed at both sites, with a maximum change of 3.7fold. The mean CV values observed for sample sets across both sites was $12.5 \%$, ranging from 7.5 to $22.3 \%$ (Tables $2 \& 3$ ).

Shifts in the percentage of HDNA cells within sample sets were usually relatively low at both sites, with a mean CV of $5 \%$ observed. However, in some samples, the absolute change in the percentage of HDNA cells was close to $20 \%$ (see Fig. 3B). We also investigated the levels of microscale variability expressed by each of the 8 cytometrically defined subpopulations. Levels of variability were always greater for the subpopulations than were observed for the community when treated as a whole, with absolute changes in abundance and CVs exceeding those observed for total counts (Tables 2 \& 3). In all but 1 of the sample-sets, the D3 population (highest green fluorescence) exhibited the highest levels of heterogeneity (Tables $2 \& 3$ ), with up to a 14.5 fold change in abundance and a CV of $52.8 \%$. Typically, for the populations differentiated according to green fluorescence level (DNA content), the degree of heterogeneity increased with increasing fluorescence levels (Tables $2 \& 3$ ). Alternatively, no clear pattern was evident for the populations separated according to SSC, with each of the populations generally exhibiting similar levels of heterogeneity (Tables $2 \& 3$ ).

\section{Microscale spatial distribution patterns}

The spatial patterns associated with the distributions of the different populations investigated here exhibited a variety of characteristics. We regularly observed
Table 3. Distributional statistics for cytometrically defined subpopulations of bacteria in samples collected from the Port River, South Australia. Skew values in bold print represent distributions that significantly differ from normal $(p<0.05)$ as assessed using Kolmogorov-Smirnov (for $10 \times 10$ data sets) and Shapiro-Wilks (for linear sample sets) tests for normality. Abbreviations as in Fig. 1 legend

\begin{tabular}{|c|c|c|c|c|}
\hline $\begin{array}{l}\text { Sample } \\
\quad \text { Population }\end{array}$ & $\begin{array}{c}\text { Mean } \\
\left(\times 10^{6} \mathrm{ml}^{-1}\right)\end{array}$ & $\begin{array}{l}\mathrm{CV} \\
(\%)\end{array}$ & Skew & $\begin{array}{c}\text { Absolute } \\
\text { change }\end{array}$ \\
\hline \multicolumn{5}{|l|}{ Linear 1} \\
\hline Total & 3.3 & 7.9 & 0.27 & 1.3 \\
\hline$\%$ HDNA & 48.2 & 4.6 & -0.9 & 1.2 \\
\hline LDNA & 1.7 & 8.7 & 0.82 & 1.3 \\
\hline D1 & 0.68 & 9 & -0.35 & 1.4 \\
\hline D2 & 0.66 & 9.9 & -0.37 & 1.5 \\
\hline D3 & 0.25 & 13.9 & -0.48 & 1.9 \\
\hline $\mathrm{S} 1$ & 0.25 & 10.9 & -0.4 & 1.5 \\
\hline S2 & 0.54 & 11.7 & -0.53 & 1.5 \\
\hline S3 & 0.54 & 10 & -0.15 & 1.4 \\
\hline $\mathrm{S} 4$ & 0.19 & 10.1 & 1.02 & 1.5 \\
\hline \multicolumn{5}{|l|}{ Linear 2} \\
\hline Total & 2.7 & 22.3 & -2.27 & 3.7 \\
\hline$\%$ HDNA & 53.6 & 8.4 & -0.54 & 1.5 \\
\hline LDNA & 1.3 & 23.6 & -2.69 & 4.7 \\
\hline D1 & 0.68 & 21.3 & -2.76 & 3.8 \\
\hline D2 & 0.63 & 27.5 & -1.23 & 3.5 \\
\hline D3 & 0.19 & 31.7 & -0.61 & 5 \\
\hline S1 & 0.22 & 25.4 & -1.01 & 2.8 \\
\hline $\mathrm{S} 2$ & 0.48 & 25.4 & -1.09 & 0.6 \\
\hline S3 & 0.48 & 23.2 & -2.12 & 3.9 \\
\hline $\mathrm{S} 4$ & 0.17 & 22.2 & -2.45 & 3.9 \\
\hline \multicolumn{5}{|l|}{ Linear 3} \\
\hline Total & 2.8 & 7.9 & -1.4 & 1.3 \\
\hline$\%$ HDNA & 57.1 & 3.7 & 0.02 & 1.2 \\
\hline LDNA & 1.2 & 9.4 & -2.08 & 1.5 \\
\hline D1 & 0.73 & 8.3 & -1.05 & 1.4 \\
\hline D2 & 0.66 & 9.5 & -0.41 & 1.3 \\
\hline D3 & 0.26 & 9.7 & -0.35 & 1.4 \\
\hline $\mathrm{S} 1$ & 0.26 & 12.8 & -0.03 & 1.5 \\
\hline $\mathrm{S} 2$ & 0.56 & 11.6 & -0.32 & 1.5 \\
\hline S3 & 0.57 & 8.1 & -0.41 & 1.3 \\
\hline $\mathrm{S} 4$ & 0.19 & 11 & 0.38 & 1.5 \\
\hline \multicolumn{5}{|l|}{ Linear 4} \\
\hline Total & 2.8 & 16.8 & 2.26 & 1.8 \\
\hline$\%$ HDNA & 58.2 & 3.4 & -0.17 & 1.1 \\
\hline LDNA & 1.2 & 19.1 & 2.65 & 2 \\
\hline D1 & 0.73 & 21 & 2.83 & 2.1 \\
\hline D2 & 0.67 & 21.4 & 2.39 & 2.2 \\
\hline D3 & 0.23 & 30.6 & -1.85 & 14.5 \\
\hline S1 & 0.27 & 23.1 & 2.36 & 2.3 \\
\hline $\mathrm{S} 2$ & 0.58 & 22.8 & 2.25 & 2.3 \\
\hline S3 & 0.57 & 20.9 & 2.54 & 2 \\
\hline $\mathrm{S} 4$ & 0.18 & 18.5 & 1.79 & 1.9 \\
\hline \multicolumn{5}{|l|}{$10 \times 10$} \\
\hline Total & 3.6 & 10.1 & -1.11 & 1.9 \\
\hline$\%$ HDNA & 50.5 & 7.5 & 0.26 & 1.7 \\
\hline LDNA & 1.77 & 13.1 & -1.17 & 2.8 \\
\hline D1 & 0.91 & 10.6 & -0.63 & 1.9 \\
\hline D2 & 0.58 & 12 & -0.42 & 2.1 \\
\hline D3 & 0.31 & 22.2 & 0.12 & 4.9 \\
\hline $\mathrm{S} 1$ & 0.18 & 16.7 & -0.33 & 2.7 \\
\hline $\mathrm{S} 2$ & 0.5 & 14.1 & -0.52 & 2.5 \\
\hline S3 & 0.81 & 12.5 & -0.24 & 2 \\
\hline S4 & 0.31 & 15.5 & 0.78 & 2.8 \\
\hline
\end{tabular}


'hotspots' where the abundance of a given population was elevated above background levels across 1 or 2 points (Figs. 2 \& 3A). Equally as common were 'cold spots', where concentrations of bacteria were lower than background levels across 1 or 2 points (see Fig. 3E,F). Several distributions were also characterised by gradients in abundance, where concentrations of a population decreased or increased across several sample points (Fig. 3B). Distributions exhibiting gradients in abundance sometimes revealed the existence of defined layers of elevated or reduced concentrations (Fig. 3B,C,D).
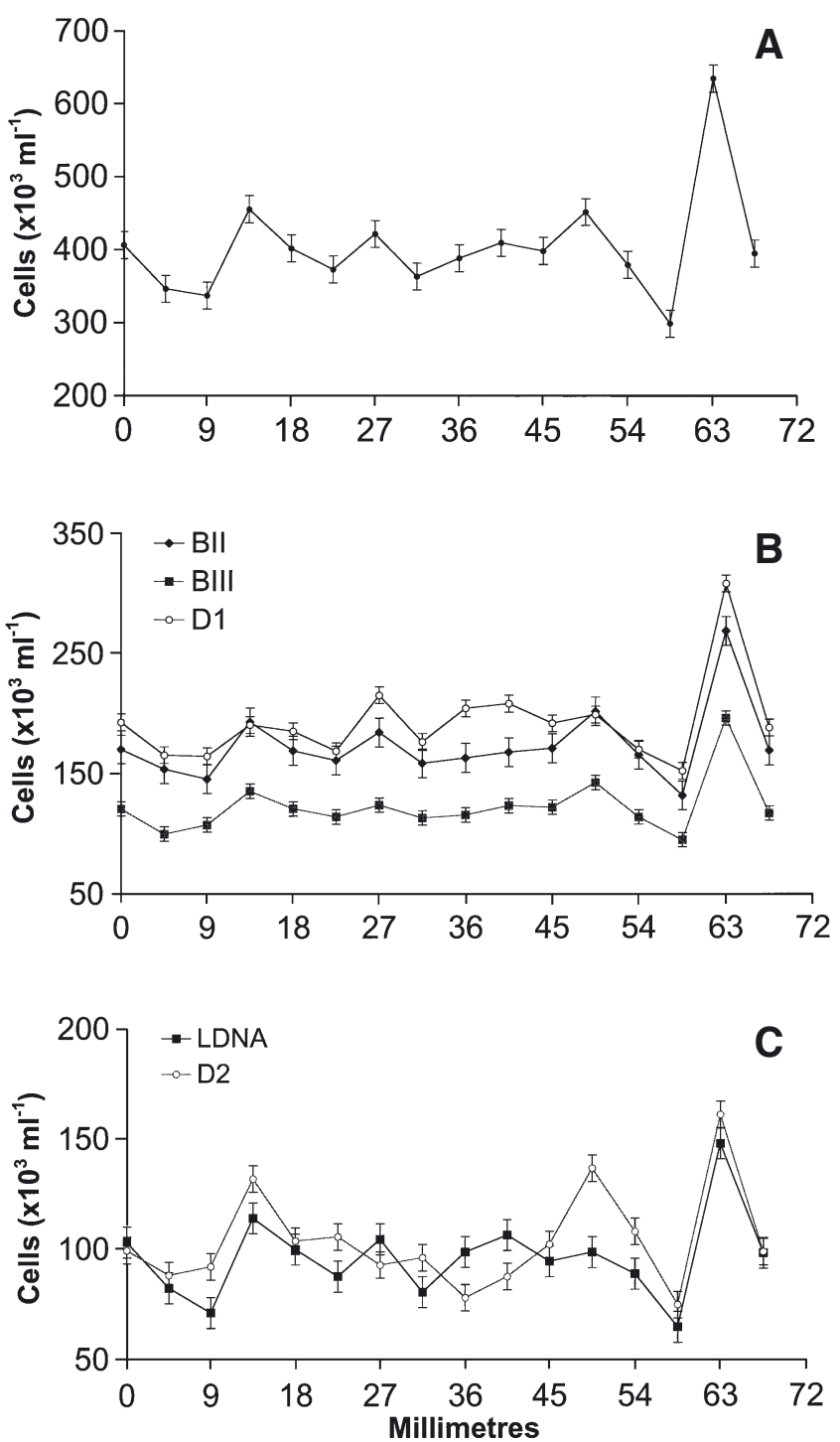

Fig. 2. Microscale horizontal linear distributions for (A) total, (B) BII, BIII, D1, and (C) LDNA and D2 populations of bacteria at Port Noarlunga (5 to $10 \mathrm{~cm}$ depth). Error bars represent $95 \%$ confidence intervals obtained from replicate $(\mathrm{n}=10)$ flow cytometry analysis of a single bulk sample $(1 \mathrm{ml})$ collected from the sample site at the time of sampling
Where rank-size analysis was employed to quantitatively measure the degree of structural complexity in spatial distributions, all populations exhibited an exponent $(b)$ value that significantly differed from zero $(\mathrm{p}<$ 0.001), indicating an absence of randomness, and the existence of spatial structure in the microscale distribution (Mitchell 2004). In all samples, the $b$ value for the total population was significantly lower $(p<0.05)$ than that calculated for each of the cytometrically defined populations, implying that the microscale structural complexity of the subpopulations was greater than when the community was treated as a single population.

\section{Comparison of distribution patterns between populations}

Comparison of the distribution patterns of bacterial subpopulations generally revealed 1 of 2 trends.

Firstly, in some samples a dominant feature of the total distribution (e.g. hotspot, coldspot or gradient) was expressed by each, or most, of the subpopulations. These sample sets were characterised by strong correlations between each of the cytometrically defined subpopulations $(\mathrm{r}>0.8, \mathrm{p}<0.05)$, and while the intensity of shifts in abundance often varied between populations, the same general distributional pattern was apparent both graphically and statistically (Fig. 2).

Secondly, we more commonly observed sample sets where the distribution patterns of the different subgroups varied (Fig. 3). In these instances, either no correlation ( $p>0.05$ ), or negative correlations between the different bacterial populations were observed. Within some samples, there was also strong divergence in the skew values calculated for different populations (Tables 2 \& 3). Positive skew can in this instance be interpreted as a distribution characterised by the presence of a few dense patches (or hotspots) over a wide range of low-density patches, while negative skewness suggests the existence of a few low-density patches (cold spots) within a wide range of high-density patches. The dissimilarities in skew values often observed here between different subpopulations within the same sample, as well as the same subpopulations between different samples, suggests that the inherent nature of the given distributions varied significantly.

Where Zipf analysis was applied, a range of $b$ values, often differing significantly $(p<0.05)$ between subpopulations, was obtained (see Fig. 4B). This implicitly infers that the microscale structures of the distributions of these populations are significantly different. The microscale structure of the distributions of subpopulations was significantly different in $71 \%$ of cases in the Port Noarlunga samples, and $86 \%$ of cases in the Port 
Fig. 3. Two-dimensional distributions of (A) total, (B) \% HDNA, (C) LDNA, (D) D1, (E) D2 and (F) D3 populations of bacteria at Port Noarlunga across an area of approximately $116 \mathrm{~cm}^{2}$. Scale bars represent cells $\times 10^{3} \mathrm{ml}^{-1}$, with the exception of (B), where they represent percentages of HDNA cells. Contour lines are set at $95 \%$ confidence intervals obtained from replicate $(n=10)$ flow cytometric analysis of a single bulk sample $(1 \mathrm{ml})$ collected from the sample site at the time of sampling
A
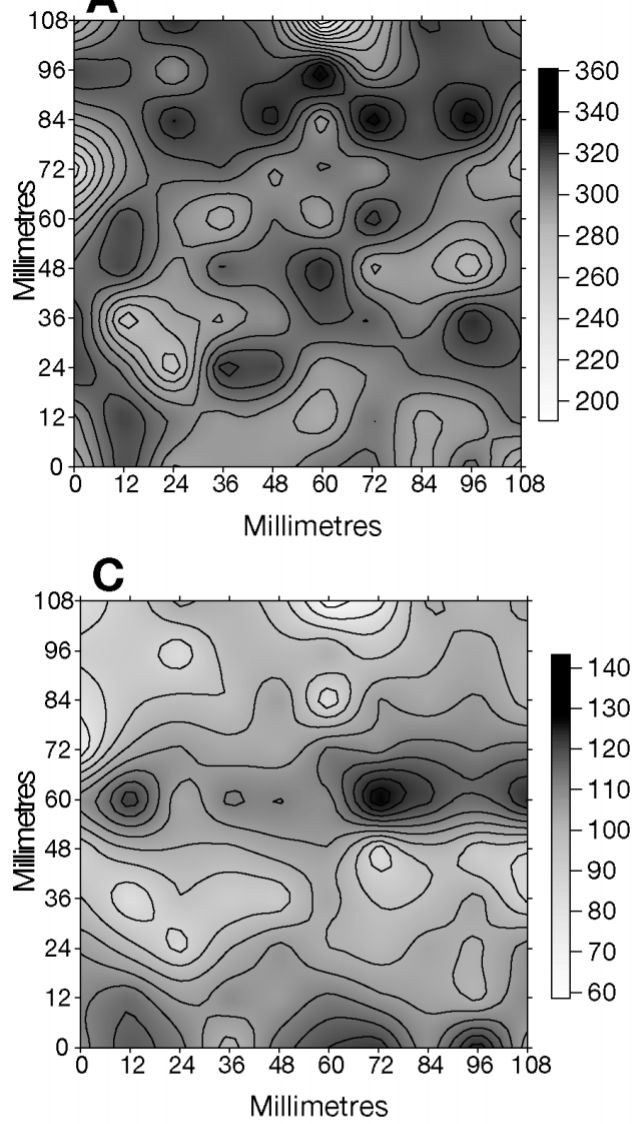

E

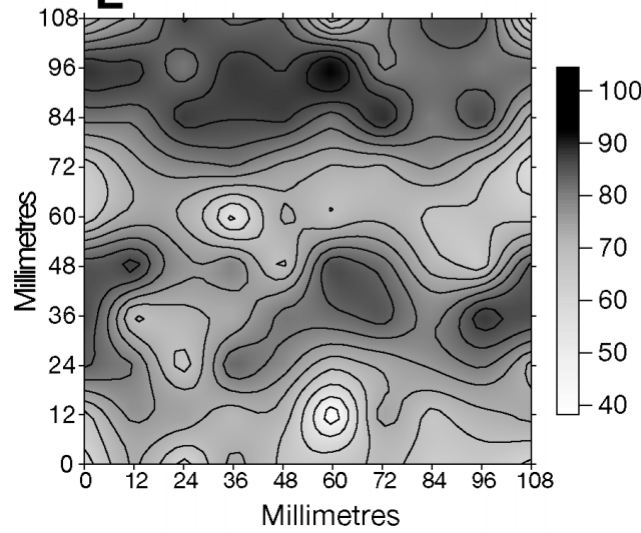

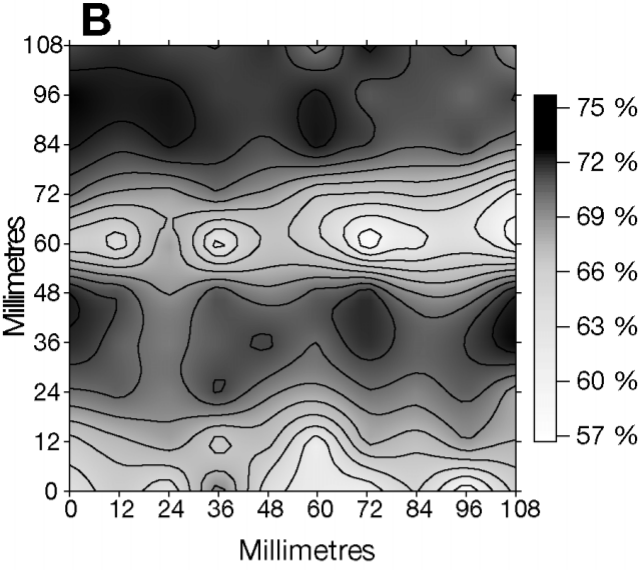
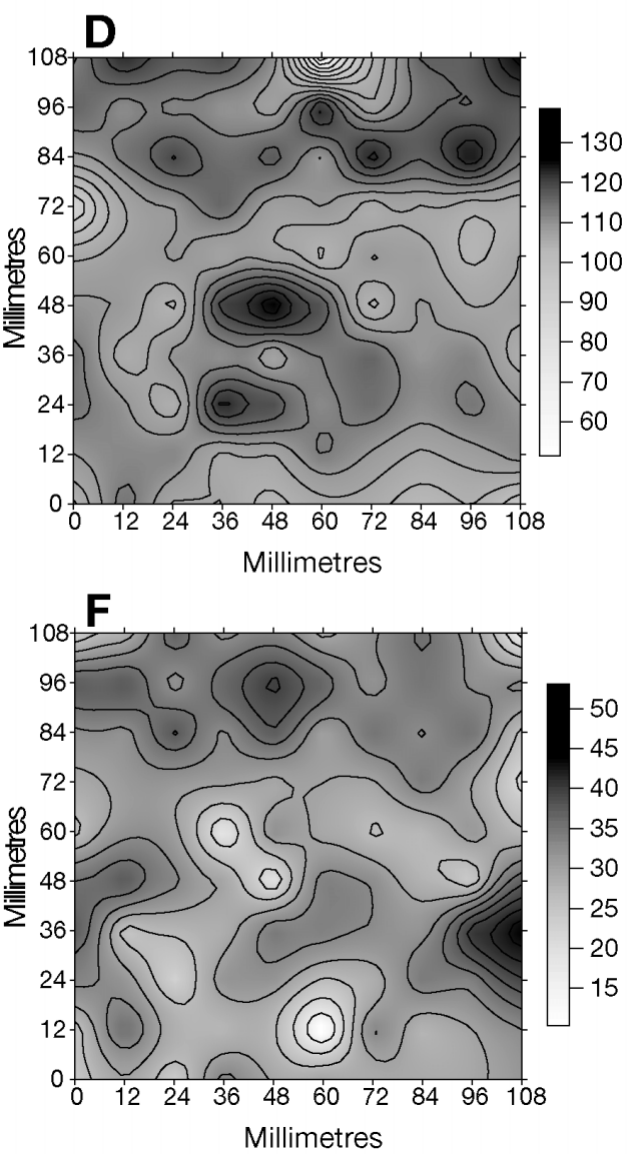

River samples. In both data sets, the D3 population always had the highest $b$ value and the total population the lowest (Fig. 4B).

\section{Microscale changes in community composition}

After ranking the cytometrically defined subpopulations according to abundance, we investigated how the rank of a given population varied between subsamples to determine how the relative numerical importance of that population changed in a microscale context. Rather than being characterised by a random or homogenous distribution of rank values, we often observed evidence for spatial patterns in the rank distribution of a given population, where 'patches', made up of adjacent samples exhibiting highly different rank values to the background, were apparent (see Fig. 5A).

To quantify the total change in the rank organisation of populations between samples, we calculated a 'distance between rank distributions' according to the methodology of Havlin (1995). This distance value $(d)$ 

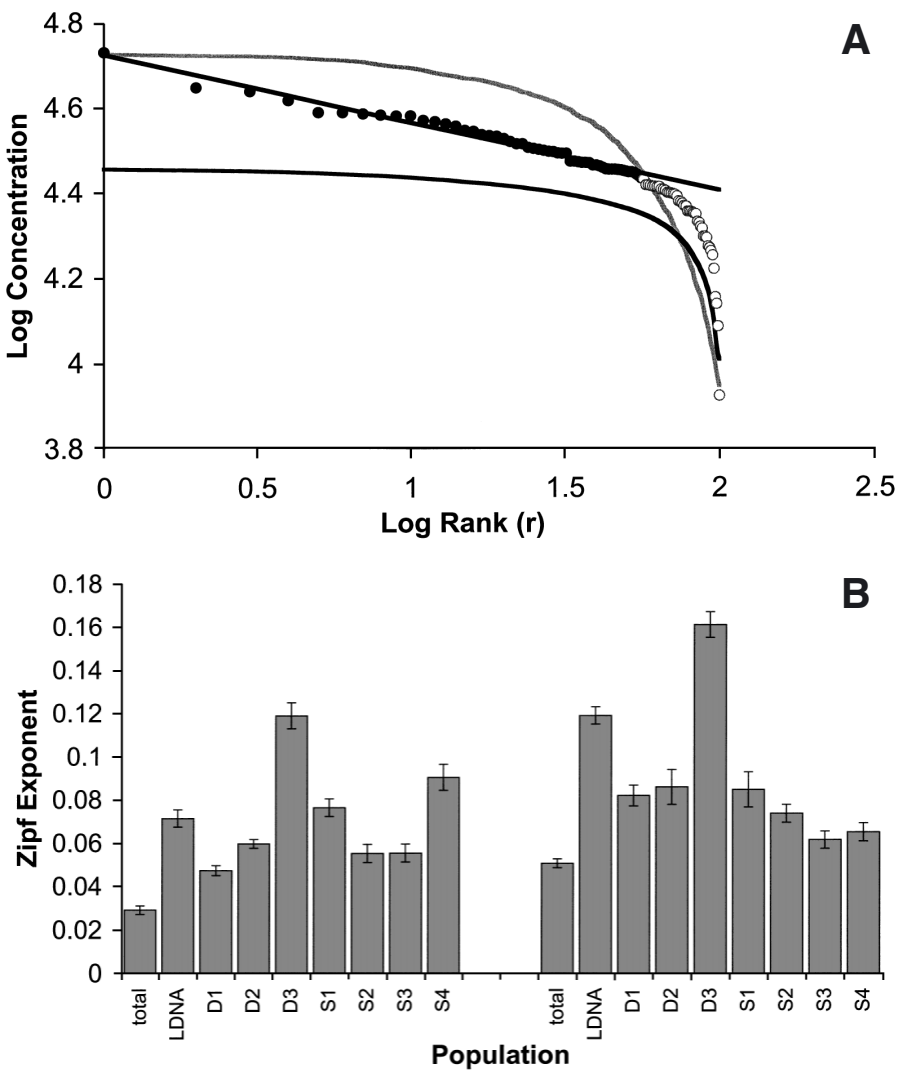

Fig. 4. (A) Zipf log-log plot of rank versus cell concentration for D3 population of bacteria at Port Noarlunga site. (O) Characteristic 'roll-off' associated with random noise subsequently omitted from determination of the Zipf exponent $b$; lower black line: results of 100 simulations of a random normal distribution with same mean and variance as the plotted D3 sample distribution; grey line: results of 100 simulations of a random uniform distribution with same mean and variance as the plotted D3 sample distribution. (B) Distribution of Zipf exponent (b) values calculated for cytometrically defined bacterial subpopulations at Port River (left) and Port Noarlunga (right). Error bars represent $95 \%$ confidence limits for slope determination

was calculated between all subsamples within a sample set, and between sample sets. The mean within-sample distance was $0.54 \pm 0.17 \mathrm{SD}$ at Port Noarlunga, and $0.35 \pm 0.06$ SD at Port River, while the mean between-sample distance was $0.20 \pm$ $0.08 \mathrm{SD}$ at Port Noarlunga, and $0.27 \pm 0.07$ SD at Port River. At Port Noarlunga, in $100 \%$ of cases the within-sample distance (i.e. the microscale distance) was greater than the between-sample distance, while at the Port River, the within-sample distance was greater than the between sample distance in $87.5 \%$ of cases.

To observe how microscale shifts in community organisation occurred within a spatial context in a given sample set, we calculated the mean rank distribution for an entire sample set and assumed that this represented the baseline, or background organisations of the bacterial community. We then calculated the distance between this baseline rank distribution and the rank distribution of each individual subsample within the sample set. This provided a graphical representation of the intensity of shifts in community organisation along a microscale transect, where low $d$ values represent small changes in the community organisation, and larger $d$ values represent greater changes from the baseline organisation. As illustrated in Fig. 5B, the spatial distributions of $d$ values regularly exhibited microscale features including gradients and multiplepoint peaks, which were similar in nature to the patterns observed for abundance distributions of bacterial populations.
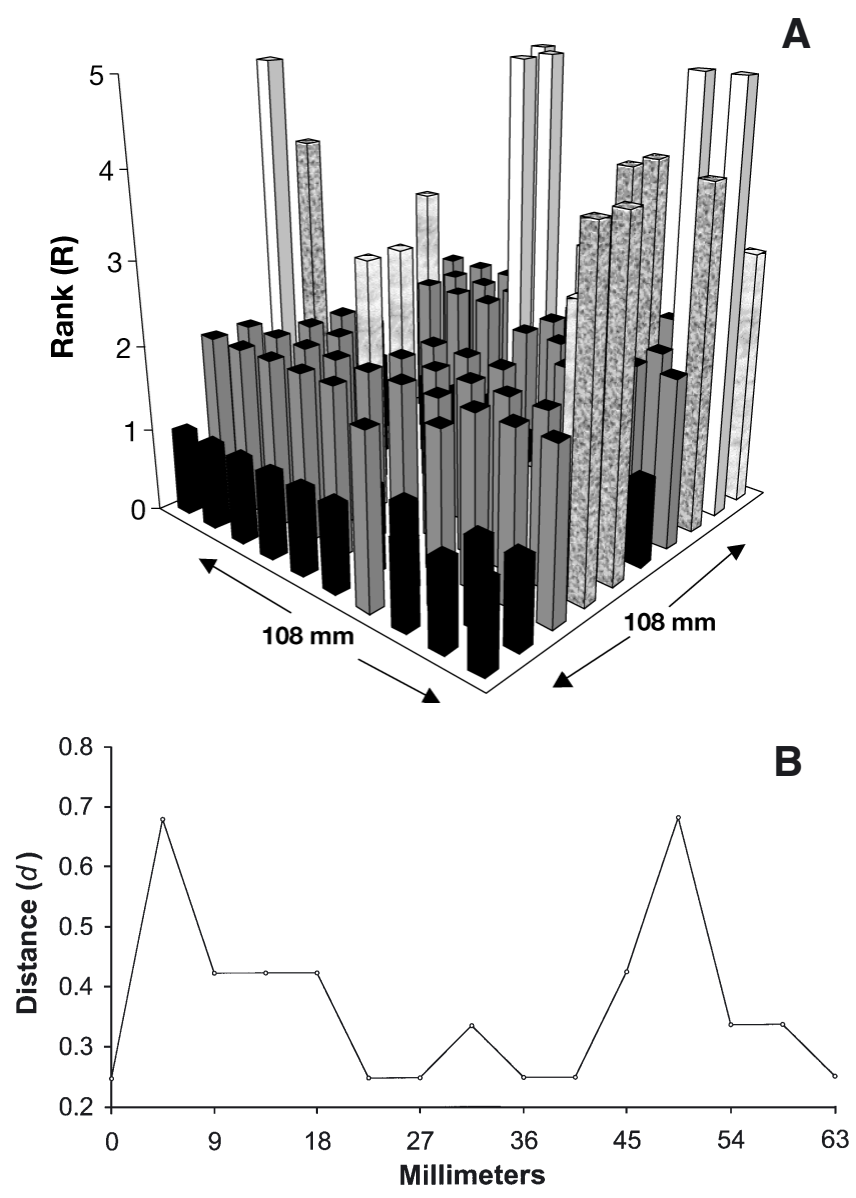

Fig. 5. (A) Two-dimensional distribution of rank values for LDNA population of bacteria in a $10 \times 10$ sample set collected from Port Noarlunga. Bars represent relative abundance rankvalues of LDNA bacteria within individual subsamples separated by a distance of $12 \mathrm{~mm}$. (B) Spatial distribution of distance between rank distribution values in a linear sample collected from Port River. Here, for a graphical representation of shifts in community organisation, distance $(d)$ was calculated between mean rank distribution for entire sample set and the rank distribution observed within each individual subsample 


\section{DISCUSSION}

Processes occurring at the ocean microscale will exert a sometimes substantial control on oceanic ecosystem functions and dynamics (Cho \& Azam 1988, Azam 1998, Kiørboe 2001, Seuront 2001). However, our current level of understanding of the physical, chemical and biological nature of the marine microenvironment is at best rudimentary. Consequently, Azam \& Long (2001) assert that 'there is an urgent need for oceanographers to embark on an exploration of the oceans at the millimetre scale'.

Here we have investigated the extent of millimetreto centimetre-scale heterogeneity in the abundance of several bacterial subpopulations representing metabolically diverse groups. We have shown that these groups are distributed heterogeneously, and that the statistical nature of the distributions differs between populations. We have also shown that the community organisation, in relation to the relative abundance of these populations, changes at the microscale. Consequently, we propose that we have provided the first evidence for microscale heterogeneity in the metabolic activity of natural bacterioplankton communities.

\section{Measuring bacterial activity}

In the last decade, a variety of single-cell specificactivity analysis techniques have been employed to measure the numbers of 'active' and 'viable' bacterial cells within aquatic systems. Amongst the most commonly used of these methodologies has been the enumeration of numbers of actively respiring cells, identified by the reduction of the fluorogenic tetrazolium dye CTC (Rodriguez et al. 1992), the enumeration of nucleoidcontaining cells (NUCC) (Zweifel \& Hagström 1995), and microautoradiography (Hoppe 1976). These techniques, among several others (Choi et al. 1996, Yamaguchi \& Nasu 1997, Williams et al. 1998, Gasol et al. 1999), probe different physiological or morphological cell features to assess states of cell activity. Varying degrees of correspondence between the fractions of active bacteria identified by these different techniques have been demonstrated (Karner \& Fuhrman 1997, Gasol et al. 1999, Berman et al. 2001), and there is currently no clear consensus on which technique most adequately assesses single-cell activity (Smith \& del Giorgio 2003), with the applicability and accuracy of some remaining highly contentious (Ullich et al. 1996, 1999, Servais et al. 2001). Additionally, and perhaps more importantly, each of these techniques can only provide relative numbers of bacteria within either 'active' or 'inactive' pools. Clearly, this is likely to be a gross simplification of the true nature of bacterioplankton communities, which are more likely to be characterised by a continuum of activity levels incorporating dead, dormant, resting, active and highly active cells (Berman et al. 2001, Smith \& del Giorgio 2003). The relative extent of each of these categories will influence both ecological and biogoechemical processes in ways that cannot be predicted by total-count techniques or inadequate activity assessments.

Using flow cytometry, Lebaron et al. (2002) were able to differentiate 14 separate populations of bacteria that were separated according to variations in DNA content and cell light-scatter, and found that levels of specific activity varied by up to 20 -fold between these groups, providing clear evidence for a continuum of bacterial activity levels in the ocean. Flow-cytometry parameters including fluorescence and light-scatter properties of cells were shown to be directly related to levels of bacterial specific activity (Lebaron et al. 2002), and we have employed these parameters to discriminate bacterial subpopulations using both histogram and scatter-plots.

If the populations studied here express similar patterns of increasing activity, with increasing fluorescence and SSC, then we may assume that they will exhibit ecologically significant variations in activity. However, here, unlike Lebaron et al. (2002), we did not cell-sort and directly measure the specific activity of each of the bacterial subpopulations. As the separation of subpopulations using flow cytometry is inherently based on the morphological features of cells, it is possible that, rather than being composed of cells of varying activity, the populations identified here vary according to morphological or taxonomic features. However, Jochem (2001) found no correspondence between common bacterial morphotypes and particular flowcytometry subpopulations. Additionally, it has been shown that flow-cytometry populations can be comprised of several different phylogenetic groups (Fuchs et al. 2000) and that cells from a given species of bacteria can occur in different flow-cytometry populations (Servais et al. 2003). This, along with the strong qualitative and quantitative field- and laboratorybased evidence to suggest that cytometrically defined populations of bacteria differ primarily on the basis of cell activity (Jellett et al. 1996, Gasol et al. 1999, 2002, Servais et al. 1999, 2003, Bernard et al. 2000, Lebaron et al. 2001, 2002, Vaqué et al. 2001), makes us confident that the populations identified here are likely to represent metabolically diverse groups.

\section{Microscale variability of bacterial abundance and activity}

There were no clear differences between the 2 study locations in either the intensity or nature of the microscale variability observed, suggesting that, at 
least in this instance, the dissimilarities in mean cell abundance, nutrient status and hydrodynamic features between the sites had no apparent bearing on the patterns observed. The mean microscale change in the abundance of the total bacterial population of approximately 2 -fold is slightly lower but comparable to those previously observed at similar scales (Seymour et al. 2000). Levels of microscale spatial heterogeneity, however, always increased significantly when the bacterial population was analysed as separate cytometrically defined subpopulations. Moreover, the slope of Zipf plots, interpreted here as a measure of the complexity of distributions, were always significantly $(p<0.05)$ higher for the cytometrically defined bacterial subpopulations than for the total population. These findings support the growing realisation that bacterial communities are more dynamic than is inferred from traditional total-count techniques (del Giorgio \& Scarborough 1995, del Giorgio et al. 1997).

Previously, distributions of cytometrically divided populations of bacteria corresponding to HDNA and LDNA categories have been investigated across large spatial and temporal scales (Li et al. 1995, Button et al. 1996, Jellett et al. 1996, Yanada et al. 2000, Jochem 2001). A general trend observed in these studies has been that, while HDNA bacteria tend to be variable with depth and season, distributions of LDNA bacteria remain relatively constant. These patterns have helped to generate the assumption that HDNA bacteria represent the active component of bacterial communities, while LDNA populations are likely to be composed of primarily dead or dormant cells (Jellett et al. 1996, Gasol et al. 1999, Vaqué et al. 2001). To our knowledge the present study is the first to investigate the microscale dynamics of these populations. While some evidence for shifts in the abundance of the LDNA population were observed here, we found that LDNA bacteria were almost always the least variable population within our sample sets (Tables 2 \& 3 ). In fact, a general trend of increasing levels of spatial variability with increasing levels of green fluorescence or DNA content was observed. In all but 1 sample set, the D3 population exhibited the highest levels of variability. This is congruent with the results of the Zipf analysis that showed that the distribution of the D3 population also always exhibited significantly $(p<0.05)$ higher levels of structural complexity than any of the other bacterial subpopulations.

The D3 subpopulation corresponds to the population of bacteria exhibiting the highest green fluorescence levels, which according to Lebaron et al. (2002) should represent some of the most active cells within the community. According to del Giorgio \& Scarborough (1995), bacterial populations in aquatic systems are likely to be characterised by a highly variable pool of rapidly growing cells embedded within a uniform matrix of inactive bacteria. Our findings provide support for this hypothesis within a microscale context. However, it is interesting to note that while strong correlations between specific activity and SSC have also been shown (Lebaron et al. 2002), we did not find evidence for trends of increasing heterogeneity or structural complexity amongst populations with increasing SSC. One potential explanation for this lack of coherence with the patterns observed for fluorescence parameters could be associated with the manner in which populations were arbitrarily separated according to SSC. These populations, unlike those divided according to fluorescence, were not divided with reference to clear cytometric features such as peaks on histograms, and it is therefore possible that these subpopulations are less likely to represent ecologically discrete groups than those separated according to such features. This suggests that caution may be required when attempting to extend cytometrically defined population dynamics to ecological processes, particularly when populations are divided according to arbitrary gates or regions (Bernard et al. 2000, Lebaron et al. 2002) rather than clearly discernible cytometric features of the population (Troussellier et al. 1999, Andreatta et al. 2001). Nevertheless, we found that the population exhibiting the highest SSC levels still exhibited the highest levels of variability and spatial structure in 40 and $50 \%$ of cases respectively.

It has been shown that scaling bacterial production measurements to either the total counts of bacteria or to the number of highly active cells produces very different estimates of bacterial growth rates (del Giorgio et al. 1997). Indeed it is becoming increasingly apparent that ecologically relevant shifts amongst bacterioplankton communities may often be masked by bulk measurements such as total counts (del Giorgio \& Bouvier 2002). We have shown that distributions of what are proposed to be the most active bacteria exhibit much higher levels of spatial variability than the average distribution of the entire community. If it is assumed that it is these bacteria that are responsible for the bulk of bacterial production and biogeochemical transformation (del Giorgio et al. 1997, Lebaron et al. 2002), then microscale variability of these parameters may be much higher than would have been predicted by considering total counts alone.

\section{Variability in distribution of subpopulations and community composition}

It is pertinent to our understanding of the existence or degree of ecological separation between the cytometrically defined populations to recognise to what 
extent these populations exhibit truly different distributional dynamics, or whether they simply each follow the average distributional pattern of the entire community. Using Zipf analysis, we found that significant similarities in the distributions of the cytometrically defined populations occurred in only $21 \%$ of cases. Divergent skew estimates for different populations within a given sample also suggest that the microscale distributions of these groups were in some cases fundamentally different. However, it is relevant to note here that these differences were in the statistical distribution of values, not necessarily in the spatial organisation of organisms. We nevertheless stress that examination of the statistical distribution, using skew estimates and Zipf analysis, provides valuable information regarding the nature of the distribution. A set of random values can be organised in space in nonrandom ways. By using Zipf analysis we have shown that the statistical distribution of the population of values is not random. This is independent of the spatial organisation and indicates that non-random processes are causing the values at each measurement point.

The application of rank-class analysis allowed us to further investigate whether microscale changes in community organisation with respect to the groups of differing metabolic activity occurred. Using this technique, shifts in community organisation were characterised by changes in the relative abundances, or ranks, of the different bacterial subpopulations within a sample. We regularly observed microscale changes in the rank structure of the community. If the subpopulations are considered here as metabolically diverse groups, this change in rank structure intrinsically suggests a fundamental change in the average activity state of the community. Additionally, rather than random fluctuations, these changes were often characterised by apparently spatially coherent patterns, whereby the relative numerical importance of 2 or more populations varied across discrete patches or gradients (Fig. 5A). To quantify total shifts in community organisation we calculated a 'distance between rank distributions' (Havlin 1995), and also observed microscale patterns that often incorporated gradients and multiple-point peaks (Fig. 5B). Long \& Azam (2001) observed similar gradients in the species richness of bacterioplankton communities across distances of millimetres, and suggested that microenvironmental processes, including bacterial interactions with particulate organic matter, may have been responsible. Our finding that shifts in community organisation within transects (i.e. between subsamples separated by $4.5 \mathrm{~mm}$ ) were greater than those observed between transects in more than $90 \%$ of cases, suggests that similar microenvironmental processes could also be important here.

\section{Causes of microscale heterogeneity}

We observed variability in the abundance and metabolic composition of bacterial populations, across millimetres to centimetres, in the form of discrete hotspots and coldspots, and across centimetres in the form of coherent gradients and layers. At larger scales, shifts in bacterioplankton activity are primarily influenced by variability in nutrients and DOC (del Giorgio \& Scarborough 1995, del Giorgio et al. 1997). At the ocean microscale, patchiness of organic and inorganic nutrients is now also predicted to be a consistent phenomenon (Lehman \& Scavia 1982, Blackburn et al. 1997, 1998, Azam 1998, Blackburn \& Fenchel 1999). Indeed, below scales of decimetres, the ocean is likely to represent a 'seascape', where distinct microenvironments may facilitate increased levels of microbial diversity and activity (Azam 1998, Long \& Azam 2001). Across scales of micrometres to millimetres, sinking and suspended organic particles influence community structure (Alldredge et al. 1986, DeLong et al. 1993) and create hotspots in bacterial abundance (Alldredge \& Silver 1988, Grossart et al. 2003), and activity (Smith et al. 1992, Ploug et al. 1999). Small particles and other polymeric materials (Koike et al. 1990, Alldredge et al. 1993, Long \& Azam 1996) may further stratify the marine environment at sub-centimetre scales by creating a 'hydrogel' or 'organic matter continuum' (Chin et al. 1998, Azam 1998), where particulate and dissolved phases blend to produce persistent gradients of organic matter (Azam 1998) and abundant organic surfaces for bacterial interactions (Long \& Azam 2001). Superimposed upon this structured microenvironment, ecological processes including cell lysis and excretion produce short-lived but potentially important patches of dissolved nutrients for bacteria (Lehman \& Scavia 1982, Blackburn et al. 1997, 1998, Blackburn \& Fenchel 1999). Across slightly larger scales of centimetres to metres, thin layers of phytoplankton (Cowles et al. 1993) and marine snow (Alldredge et al. 2002), as well as intermittent nutrient patches (Seuront et al. 2002), and solute plumes associated with sinking aggregates (Kiørboe et al. 2001, Kiørboe \& Jackson 2001) will create microhabitats where bacterial activity and growth may also be enhanced.

Top-down processes, including grazing by protozoan bacterivores, as well as viral infection, also play an important role in structuring bacterioplankton communities (Fuhrman 1999, Pedrós-Alio et al. 2000), and have been shown to be specific to both the size (González et al. 1990, Jürgens \& Güde 1994, Weinbauer \& Höfle 1998) and activity (del Giorgio et al. 1996) of bacteria cells. In fact, bacterivorous flagellates have been shown to consume HDNA bacteria in preference to LDNA bacteria (Gasol et al. 1999, Vaqué et al. 2001). It therefore follows that grazing pressure 
could also influence the relative abundance and spatial distributions of the cytometrically defined subpopulations observed here.

Clearly, a diverse suite of processes can potentially generate a distinctly inhomogeneous environment at the ocean microscale. However, we can as yet only speculate on the relative importance of any one, or any group, of these structuring mechanisms in influencing and structuring the microscale distribution and composition of the bacterioplankton subpopulations investigated here.

\section{Implications and conclusions}

If a ubiquitous feature of the marine environment, the patterns and types of heterogeneity observed here may profoundly influence ecological and biogeochemical processes at scales ranging from drops of seawater to ocean basins (Azam 1998). Microscale patchiness in bacterial activity will influence the rates and distribution of bacterial uptake of dissolved organic substrates, as well as potentially altering predator-prey and viral infection dynamics, which will fundamentally affect the flow of materials through the microbial loop (Azam et al. 1983). This will have implications that extend beyond microbial food web structure and functions to higher trophic levels.

In a biogeochemical sense, the transformation of sinking POC to DOC, which ultimately determines ocean carbon flux rates, is controlled not by bulkphase bacterial activity, but by the activity of bacteria within microhabitats associated with sinking organic particles (Azam \& Long 2001). Similarly, bacterial cycling of inorganic nutrients and minerals often occurs only within specific microzones (Paerl 1985, Bidle \& Azam 1999). Consequently, shifts in bacterial activity associated with these microscale processes will influence ocean-basin-scale biogeochemistry (Azam 1998) and even global climate (Ducklow \& Fasham 1992) to an extent that cannot be predicted by bulkphase analysis.

Clearly, if an appreciation of the extent of microscale variability in microbial dynamics in the ocean is not recognised, then an inaccurate perception of the marine environment may be attained. Here we have presented evidence for the existence of microscale heterogeneity in the abundance of metabolically diverse groups of bacteria. While the extent of this heterogeneity was found to vary markedly, and has as yet only been investigated in 2 coastal habitats, we believe that the demonstration of its existence is an important addition to the emerging field of microscale oceanography, and reveals a new degree of complexity amongst marine microbial communities.
Acknowledgements. The authors gratefully acknowledge S. Bailey and P. Macardle from the Flow Cytometry Unit of The Flinders Medical Centre, for providing technical support in flow cytometry. We also thank D. Edyvean for constructing the $10 \times 10$ two-dimensional sampling device. Further thanks to N. Patten for providing chlorophyll data, and the captain and staff of the MV 'Port Princess' for allowing us to use their floating pontoon platform in the Port River. Helpful comments on the manuscript were provided by 3 anonymous reviewers. Funding for this research was provided by the Australian Research Council and the Flinders University School of Biological Sciences. The Flinders University Faculty of Science and Engineering provided a visiting scientist fellowship to L.S.

\section{LITERATURE CITED}

Alldredge AL, Silver M (1988) Characteristics, dynamics and significance of marine snow. Prog Oceanogr 20:41-82

Alldredge AL, Cole JJ, Caron DA (1986) Production of heterotrophic bacteria inhabiting macroscopic organic aggregates (marine snow) from surface waters. Limnol Oceanogr 31:68-78

Alldredge AL, Passow U, Logan BE (1993) The abundance and significance of a class of large, transparent organic particles in the ocean. Deep-Sea Res 40:1131-1140

Alldredge $\mathrm{AL}$, Cowles TJ, MacIntyre S, Rines JEB and 6 others (2002) Occurrence and mechanisms of formation of a dramatic thin layer of marine snow in a shallow Pacific fjord. Mar Ecol Prog Ser 233:1-12

Alon N, Gibbons PB, Matias Y, Szegedy M (2002) Tracking join and self-join sizes in limited storage. J Com Syst Sci 64:719-747

Andreatta S, Wallinger MM, Posch T, Psenner R (2001) Detection of subgroups from flow cytometry measurements of heterotrophic bacterioplankton by image analysis. Cytometry 44:218-225

Azam F (1998) Microbial control of oceanic carbon flux: the plot thickens. Science 280:694-696

Azam F, Long RA (2001) Sea snow microcosms. Nature 414: 495-498

Azam F, Fenchel T, Field JG, Gray JS, Meyer-Reil LA, Thingstad F (1983) The ecological role of water-column microbes in the sea. Mar Ecol Prog Ser 10:257-263

Berman T, Kaplan B, Chava S, Viner Y, Sher BF, Sherr EB (2001) Metabolically active bacteria in Lake Kinneret. Aquat Microb Ecol 23:213-224

Bernard L, Courties C, Servais P, Troussellier M, Petit M, Lebaron P (2000) Relationships among bacterial cell size, productivity and genetic diversity in aquatic environments using cell sorting and flow cytometry. Microb Ecol 40: $148-158$

Bidle KD, Azam F (1999) Accelerated dissolution of diatom silica by marine bacterial assemblages. Nature 397:508-512

Blackburn N, Fenchel T (1999) Influence of bacteria, diffusion and shear on micro-scale nutrient patches, and implications for bacterial chemotaxis. Mar Ecol Prog Ser 189:1-7

Blackburn N, Azam F, Hagström $\AA$ (1997) Spatially explicit simulations of a microbial food web. Limnol Oceanogr 42: 613-622

Blackburn N, Fenchel T, Mitchell JG (1998) Microscale nutrient patches in plankton habitats shown by chemotactic bacteria. Science 282:2254-2256

Button DK, Robertson BR, Jüttner F (1996) Microflora of a subalpine lake: bacterial populations, size, and DNA distributions, and their dependence on phosphate. FEMS Microbiol Ecol 21:87-101 
Chin WC, Orellana MV, Verdugo P (1998) Spontaneous assembly of marine dissolved organic matter into polymer gels. Nature 391:568-572

Cho BC, Azam F (1988) Major role of bacteria in biogeochemical fluxes in the ocean's interior. Nature 332:441-443

Choi JW, Sherr EB, Sherr BF (1996) Relation between presence-absence of a visible nucleoid and metabolic activity in bacterioplankton cells. Limnol Oceanogr 41:1161-1168

Cowles TJ, Desiderio RA, Neuer WS (1993) In situ characterisation of phytoplankton from vertical profiles of fluorescence spectra. Mar Biol 115:217-222

del Giorgio PA, Bouvier TC (2002) Linking the physiological and phylogenetic successions in free-living bacterial communities along an estuarine salinity gradient. Limnol Oceanogr 47:471-486

del Giorgio PA, Scarborough G (1995) Increase in the proportion of metabolically active bacteria along gradients of enrichment in freshwater and marine plankton: implications for estimates of bacterial growth and production rates. J Plankton Res 17:1905-1924

del Giorgio PA, Gasol JM, Vaqué D, Mura P, Agustí S, Duarte CM (1996) Bacterioplankton community structure: protists control net production and the proportion of active bacteria in a coastal marine community. Limnol Oceanogr 41: 1169-1179

del Giorgio PA, Prairie YT, Bird DF (1997) Coupling between rates of bacterial production and the abundance of metabolically active bacteria in lakes, enumerated using CTC reduction and flow cytometry. Microb Ecol 34:144-154

DeLong EF, Franks DG, Alldredge AL (1993) Phylogenetic diversity of aggregate-attached vs free-living marine bacterial assemblages. Limnol Oceanogr 38:924-934

Duarte CM, Vaqué D (1992) Scale dependence of bacterioplankton patchiness. Mar Ecol Prog Ser 84:95-100

Ducklow HW, Fasham MJR (1992) Bacteria in the greenhouse: modelling the role of oceanic plankton in the global carbon cycle. In: Mitchell R (ed) Environmental microbiology. Wiley-Liss, New York, p 1-31

Fuchs BM, Zubkov MV, Sam K, Burkhill PH, Amann R (2000) Changes in community composition during dilution cultures of marine bacterioplankton as assessed by flow cytometry and molecular biological techniques. Environ Microbiol 2:191-201

Fuhrman JA (1999) Marine viruses and their biogeochemical and ecological effects. Nature 399:541-548

Gasol JM, del Giorgio PA (2000) Using flow cytometry for counting natural planktonic bacteria and understanding the structure of planktonic bacterial communities. Sci Mar 64(2):197-224

Gasol JM, Doval MD, Pinhassi J, Calderón-Paz JI, GuixaBoixareu N, Vaqué D, Pedrós-Alió C (1998) Diel variations in bacterial heterotrophic activity and growth in the northwestern Mediterranean Sea. Mar Ecol Prog Ser 164: $107-124$

Gasol JM, Zweifel UL, Peters F, Fuhrman JA, Hagström ^ (1999) Significance of size and nucleic acid content heterogeneity as measured by flow cytometry in natural planktonic bacteria. Appl Environ Microbiol 65: $4475-4483$

Gasol JM, Comerma M, García JC, Armengol J, Casamayor EO, Kojecká P, Šimek K (2002) A transplant experiment to identify the factors controlling bacterial abundance, activity, production, and community composition in a eutrophic canyon-shaped reservoir. Limnol Oceanogr 47:62-77

González JM, Sherr EB, Sherr BF (1990) Size-selective grazing on bacteria by natural assemblages of estuarine flagellates and ciliates. Appl Environ Microbiol 56:583-589
Grossart HP, Hietanen S, Ploug H (2003) Microbial dynamics on diatom aggregates in Øresund, Denmark. Mar Ecol Prog Ser 249:69-78

Gunther R, Levitin L, Schapiro B, Wagner P (1996) Zipf's law and the effect of ranking on probability distribution. Int $\mathrm{J}$ Theor Phys 35:395-417

Havlin S (1995) The distance between Zipf plots. Physica A 216:148-150

Hill BM (1970) Zipf's law and prior distributions for the composition of a population. J Am Stat Assoc 65:1220-1232

Hoppe HG (1976) Analysis of actively metabolizing bacterial populations with the autoradiographic method. In: Rheinheimer G (ed) Microbial ecology of a brackish water environment. Springer-Verlag, Berlin, p 179-197

Jellett JF, Li WKW, Dickie PM, Boraie A, Kepkay PE (1996) Metabolic activity of bacterioplankton communities assessed by flow cytometry and single carbon substrate utilisation. Mar Ecol Prog Ser 136:213-225

Jochem FJ (2001) Morphology and DNA content of bacterioplankton in the northern Gulf of Mexico: analysis by epifluorescence microscopy and flow cytometry. Aquat Microb Ecol 25:179-194.

Jürgens K, Güde H (1994) The potential importance of grazing-resistant bacteria in planktonic systems. Mar Ecol Prog Ser 112:169-188

Karner M, Fuhrman JA (1997) Determination of active marine bacterioplankton; a comparison of universal 16S rRNA probes, autoradiography, and nucleoid staining. Appl Environ Microbiol 63:1208-1213

Kiene RP, Linn LJ, Bruton JA (2000) New and important roles for DMSP in marine microbial communities. J Sea Res 43: $209-224$

Kiørboe T (2001) Formation and fate of marine snow: smallscale processes with large scale implications. Sci Mar 65: $57-71$

Kiørboe T, Jackson GA (2001) Marine snow, organic solute plumes, and optimal chemosensory behaviour of bacteria. Limnol Oceanogr 46:1309-1318

Kiørboe T, Ploug H, Thygesen UH (2001) Fluid motion and solute distribution around sinking aggregates. I. Smallscale fluxes and heterogeneity of nutrients in the pelagic environment. Mar Ecol Prog Ser 211:1-13

Koike I, Shigemitsu H, Kazuki T, Kogure K (1990) Role of submicrometer particles in the ocean. Nature 345:242-244

Krembs C, Juhl AR, Long RA, Azam F (1998) Nanoscale patchiness of bacteria in lake water studied with the spatial information preservation method. Limnol Oceanogr 43:307-314

Lebaron P, Servais P, Agogué H, Courties C, Joux F (2001) Does the high nucleic acid content of individual bacterial cells allow us to discriminate between active cells and inactive cells in aquatic systems? Appl Environ Microbiol $67(4): 1775-1782$

Lebaron P, Servais P, Baudox AC, Bourrain M, Courties C, Parthuisot N (2002) Variations of bacterial specific activity with cell size and nucleic acid content assessed by flow cytometry. Aquat Microbiol Ecol 28:131-140

Lehman JT, Scavia D (1982) Microscale patchiness of nutrients in plankton communities. Science 216:729-730

Li W, Yang Y (2002) Zipf's law in importance of genes for cancer classification using microarray data. J Theor Biol 219:539-551

Li WKW, Jellet JF, Dickie PM (1995) DNA distributions in planktonic bacteria stained with TOTO or TO-PRO. Limnol Oceanogr 40:1485-1495

Long RA, Azam F (1996) Abundant protein-containing particles in the sea. Aquat Microb Ecol 10:213-221 
Long RA, Azam F (2001) Microscale patchiness of bacterioplankton assemblage richness in seawater. Aquat Microb Ecol 26:103-113

Marie D, Partensky F, Jacquet S, Vaulot D (1997) Enumeration and cell cycle analysis of natural populations of marine picoplankton by flow cytometry using a novel nucleic acid dye. Appl Environ Microbiol 63:186-193

Marie D, Partensky F, Vaulot D, Brussard C (1999) Enumeration of phytoplankton, bacteria and viruses in marine samples. Current Protocols Cytometry 11.11.1-11.11.15.

Marsili M, Zhang YC (1998) Interacting individuals leading to Zipf's law. Phys Rev Lett 80:2741-2744

Mitchell JG (2004) Rank-size analysis and vertical phytoplankton distribution patterns. In: Seuront L, Strutton PG (eds) Handbook of scaling methods in aquatic ecology: measurements, analysis, simulation. CRC Press, Boca Raton, FL, p 257-278

Mitchell JG, Fuhrman JA (1989) Centimeter scale vertical heterogeneity in bacteria and chlorophyll a. Mar Ecol Prog Ser 54:141-148

Paerl HW (1985) Microzone formation: its role in the enhancement of aquatic $\mathrm{N}_{2}$ fixation. Limnol Oceanogr 30: 1246-1252

Pedrós-Alio C, Calderón JI, Gasol JM (2000) Comparative analysis shows that bacterivory, not viral lysis, controls the abundance of heterotrophic prokaryotic plankton. FEMS Microbiol Ecol 32:157-165

Ploug H, Grossart HP, Azam F, Jørgensen BB (1999) Photosynthesis, respiration, and carbon turnover in sinking marine snow from surface waters of Southern California Bight: implications for the carbon cycle in the ocean. Mar Ecol Prog Ser 179:1-11

Ridley DR, Gonzalez EA (1994) Zipf's law extended to small samples of adult speech. Percept Mot Skills 79:153-154

Riemann L, Middelboe M (2002) Stability of bacterial and viral community compositions in Danish coastal waters as depicted by DNA fingerprinting techniques. Aquat Microb Ecol 27:219-232

Riemann L, Steward GF, Fandido LB, Campbell L, Landry MR, Azam F (1999) Bacterial community composition during 2 consecutive NE monsoon periods in the Arabian Sea studied by denaturing gradient gel eletctrophoresis (DGGE) of rRNA genes. Deep-Sea Res II 46:1791-1811

Rodriguez GG, Ishiguro DP, Ridgway HF (1992) Use of fluorescent redox probe for direct visualisation of actively respiring bacteria. Appl Environ Microbiol 58:1801-1808

Servais P, Courties C, Lebaron P, Troussellier M (1999) Coupling bacterial activity measurements with cell sorting by flow cytometry. Microb Ecol 38:180-189

Servais P, Agogué H, Courties C, Joux F, Lebaron P (2001) Are the actively respiring cells (CTC+) those responsible for bacterial production in aquatic environments? FEMS Microbiol Ecol 35:171-179

Servais P, Casamayor EO, Courties C, Catala P, Parthuisot N, Lebaron P (2003) Activity and diversity of bacterial cells with high and low nucleic acid content. Aquat Microb Ecol 33:41-51

Seuront L (2001) Microscale processes in the ocean: why are they so important for ecosystem functioning? La Mer 39: $1-8$

Seuront L, Spilmont N (2002) Self-organized criticality in intertidal microphytobenthos patch patterns. Physica A 313:513-539

Seuront L, Gentilhomme V, Lagadeuc Y (2002) Small-scale nutrient patches in tidally mixed coastal waters. Mar Ecol

Editorial responsibility: Jed Fuhrman,

Los Angeles, California, USA
Prog Ser 232:29-44

Seymour JR, Mitchell JG, Pearson L, Waters R (2000) Heterogeneity in bacterioplankton abundance from 4.5 millimetre resolution sampling. Aquat Microb Ecol 22:143-153

Simo R, Archer SD, Pedros-Alio C, Gilpin L, Stelfox-Widdicombe CE (2002) Coupled dynamics of dimethylsulfoniopropionate and dimethylsulfide cycling and the microbial food web in surface waters of the North Atlantic. Limnol Oceanogr 47:53-61

Smith DC, Simon M, Alldredge AL, Azam F (1992) Intense hydrolytic enzyme activity on marine aggregates and implications for rapid particle dissolution. Nature 359:139

Smith EM, del Giorgio PA (2003) Low fractions of active bacteria in natural aquatic communities? Aquat Microb Ecol 31:203-208

Stanley MHR, Buldyrev SV, Havlin S, Mantegna RN, Salinger MA, Stanley HE (1995) Zipf's plots and the size distribution of firms. Econom Lett 49:453-457

Troussellier M, Courties C, Lebaron P, Servais P (1999) Flow cytometric discrimination of bacterial populations in seawater based on SYTO 13 staining of nucleic acids. FEMS Microbiol Ecol 29:319-330

Ullrich S, Karrasch B, Hoppe HG, Jeskulke K, Mehrens M (1996) Toxic effects on bacterial metabolism of the redox dye 5-cyano-2,3-ditolyl tetrazolium chloride. Appl Environ Microbiol 62:4587-4593

Ullrich S, Karrasch B, Hoppe HG (1999) Is the CTC dye technique an adequate approach for estimating active bacteria cells? Aquat Microb Ecol 17:207-209

Vaqué D, Casamayor EO, Gasol JP (2001) Dynamics of whole community bacterial production and grazing losses in seawater incubations as related to the changes in the proportions of bacteria with different DNA content. Aquat Microb Ecol 25:163-177

Vaulot D (1989) CytoPC: processing software for flow cytometric data. Signal Noise 2:8

Waters RL, Mitchell JG, Seymour J (2003) Geostatistical characterisation of centimetre-scale spatial structure of in vivo fluorescence. Mar Ecol Prog Ser 251:49-58

Weinbauer MG, Höfle MG (1998) Size specific mortality of lake bacterioplankton by natural virus communities. Aquat Microb Ecol 15:103-113

Williams SC, Hong Y, Danavall DCA, Howard-Jones MH, Gibson D, Frischer ME, Verity PG (1998) Distinguishing between living and nonliving bacteria: evaluation of the vital stain propidium iodide and the combined use with molecular probes in aquatic samples. J Microbiol Methods 32:225-236

Wyllys RE (1975) Measuring scientific prose with rank frequency (Zipf) curves: a new use for an old phenomenon. Proc Am Soc Inf Sci 12:30-31

Yamaguchi N, Nasu M (1997) Flow cytometric analysis of bacterial respiratory and enzymatic activity in the natural aquatic environment. J Appl Microbiol 83:43-52

Yanada M, Yokokawa T, Lee CW, Tanaka H, Kudo I, Maita Y (2000) Seasonal variation of 2 different heterotrophic bacterial assemblages in subarctic coastal seawater. Mar Ecol Prog Ser 204:289-292

Zar JH (1984) Biostatistical analysis, 2nd edn. Prentice-Hall, Englewood Cliffs, NJ

Zipf GK (1949) Human behaviour and the principle of least effort. Addison-Wesley, Cambridge, MA

Zweifel UL, Hagström $\AA$ (1995) Total counts of marine bacteria include a large fraction of non-nucleoid-containing bacteria (ghosts). Appl Environ Microbiol 61:2180-2185 